\title{
Efficiency of Retail Enterprises in Context of Achievement of Competitive Advantages: Ukrainian Realities
}

\author{
Maryna Chorna ${ }^{1}$, Lyubov Bezghinova ${ }^{1}$, Oleksandr Dorokhov ${ }^{2}$, \\ Iryna Zhuvahina $^{3}$, Anatoly Volosov ${ }^{1}$ \\ ${ }^{1}$ Kharkiv State University of Food Technology and Trade, Ukraine \\ ${ }^{2}$ Simon Kuznets Kharkiv National University of Economics, Ukraine \\ ${ }^{3}$ Pervomaisk Branch of Admiral Makarov National University of Shipbuilding, Ukraine
}

\begin{abstract}
The development of trade sector of the Ukrainian economy triggers the need to study the processes of formation and evaluation of the retail business efficiency taking into account the current conditions of economic development.

The objective of research is a methodology for assessing the performance of retail.

The proposed methodology is based on the target, resource, dynamic approaches to the efficiency assessment and contains determined efficiency indicators in accordance with evaluation criteria.

The indicators of the efficiency assessment take into account the specifics of the retail according to the subjects of assessment: retailer, consumer, competitor, supplier.

Proposed methodology for assessing the efficiency allows us to calculate indicators in accordance with the selected approaches to the assessment and identify the problems to be addressed by the retailer's management.

Considering the requirements and interests of stakeholders to assess the efficiency of retail businesses helps to achieve the most recent competitive advantages.
\end{abstract}

DOI: $10.18421 /$ TEM103-10

https://doi.org/10.18421/TEM103-10

Corresponding author: Oleksandr Dorokhov,

Simon Kuznets Kharkiv National University of Economics, Kharkiv, Ukraine.

Email: aleks.dorokhov@meta.ua

Received: 28.03.2021.

Revised: 06.07.2021.

Accepted: 12.07.2021.

Published: 27. 08. 2021.

(c) BY-NC-ND (C) 2021 Maryna Chorna et al; published by UIKTEN. This work is licensed under the Creative Commons Attribution-NonCommercial-NoDerivs 4.0 License.

The article is published with Open Access at www.temjournal.com
Keywords -retail trade, efficiency, goal achievement, performance, resource intensity, competitive advantages.

\section{Introduction}

Efficiency is the basis for successful activity of any business entity and forms the ground for its further development in a competitive environment.

Actions aimed at improving the efficiency of activities, determine the specific measures that promote the development of the business entity and its support at the proper level, and exclude those that cause a recession.

Therefore, the importance of assessing the efficiency of the enterprise is extremely relevant throughout its period of operation.

Organization of effective economic activity is one of the important factors for successful retail business, and the evaluation of efficiency is an objective basis for the formation of their development vector in a competitive environment.

This evaluation provides complete and objective information for managerial decisions in all areas of activity aimed at achieving competitive advantages.

Regular evaluation of the current results is one of the conditions for successful functioning in a competitive market environment.

For the successful operation and development of enterprises in modern conditions, which are characterized by growing competition against significant uncertainty of environmental factors and increasing requirements of stakeholders, business entities have to form new and maintain existing competitive advantages.

The basis of ensuring long-term competitive advantages of retailers is, first of all, the availability of their own funds, stable financial status and image of the company, powerful competitive potential and the possibility of introducing innovative technologies, which is formed due to its high efficiency. 
Thus, a regular assessment of the current results of retailer's activity is one of the conditions for successful functioning in a competitive market environment.

\section{Literatire Background}

The global valuation practice has many methods and approaches to evaluate the efficiency of the business entity.

The traditional financial model of evaluation (Dupont model), which was first used in the early period of the last century, has been and is the most widely used in foreign practice and has been upgraded with the development of accounting methods.

Despite its active application, we should note the presence of certain shortcomings - focused orientation (considers the material factors only when evaluates efficiency), limited information content (neglects changes that have occurred with the owner's capital), and relative accuracy (the data of accounting reports does not provide accurate representation about the state of the company).

An alternative to the traditional financial model is the various cost models of economic efficiency evaluation, which associate enhancement of efficiency with an increase in value [3], [17].

According to this approach, market value is considered as a complex criterion / indicator of the evaluation of the company's efficiency compared to traditional performance indicators that characterize certain economic aspects of its activities.

The basis of valuation methods is the calculation of cash flows, value, value added, and the combination of income and assets using the values given.

In [18] the author of one of the first cost models, noted that in the presence of alternative investment options, one should strive to achieve a balance between high risk and low risk investments in the investment portfolio.

He proposed the concept of "Q ratio" (Tobin's ratio), which is defined as the ratio of the market value of tangible assets to the cost of their replacement and is used to determine the efficiency of capital investments in the company.

In [3] a different approach is proposed to distinguish cost ratios based on the calculation of the cost index as a discounted cash flow of the company.

This approach takes into account all available factors from the internal or external environment of the company that may affect the results of the activity, making it more adapted to assess the economic efficiency of the company.

In the framework of developing a system that would allow monitoring the change in value, researchers proposed to distinguish cost ratios (with only financial indicators considered) and set them as efficiency indicators for different units.

Improved management and planning, the development of information technology, increased competition and complexity of tasks have contributed to the high-quality development of cost-effective methods for evaluating the efficiency.

One of the methods for assessing economic profit in corporate finances is the concept of economic value added (EVA) by [17], which understands the increase in efficiency as exceeding the profitability of the capital used over the costs for its attraction.

The EVA-based management should ensure a stable, inalienable value of this indicator, while maximizing the growth of EVA with effective asset management is reduced to the identification of factors that allow the company to increase operating profit and minimize the cost of employed capital at its optimal structure.

Other existing methods, such as Balanced Scorecards [9], Tableau de Bord [5], [15], Performance Prisms [13], and etc., can also be used to assess the company's performance.

Thus, the need to create a technology for a balanced system of indicators was due to the gradual loss of market benefits of companies, which use only financial indicators in the assessment of their activities.

Instead, the success of a modern company depends more on its intangible assets (brand value, customer loyalty, competitive advantage, innovation activity, etc.) whose performance cannot be measured by conventional financial accounting.

In accordance with this concept, company management should track not only revenue and profit, but also other criteria related to customer relationships, improvement of internal business processes, etc.

Today, Balanced Scorecards [9] is simultaneously the basis of strategic management and a system for assessing the company's efficiency, based on the transformation of its mission and strategy into a system of interconnected indicators.

It is widely used both in developed countries and in Ukraine.

According to [9], the set of indicators of Balanced Scorecards depends on the type of activity and key factors of the company's success and is aimed at determining whether the strategy leads to the final results - the creation of value for the defined projections (finances, clients, internal business processes, training and development).

The key indicators of the client component (such as market share, customer maintenance and expansion, customer satisfaction, and customer profitability) allow, according to the authors, 
correlating them with the status of target client groups and market segments, determining the consumer value of the offers that serve as important indicators under time to evaluate the results of customer relations.

The projection of internal business processes is represented by important internal operational and production processes that require perfection, which will enable the company: firstly, to develop such business offers to consumers that will help create and maintain a client base in the target market segment; and secondly, to satisfy the expectations of owners regarding high financial returns.

Within the "learning and development" component, three main areas are identified: 1) the employee's abilities; 2) the capabilities of information systems; and 3) motivation, a delegation of authority, matching of personal goals to corporate ones, and corresponding to each evaluation indicator.

Balanced Scorecards is intended for the specifics of the economy of developed countries, and therefore in the original form cannot be applied by Ukrainian enterprises. This system has improved and adapted to the requirements of the Ukrainian economic situation, subject to the industrial specifics of the company.

The methods of integrated assessment of business efficiency, which were developed after Ukraine became independent (after 1991) are of some research interest.

At present, the main problem of the management of domestic enterprises is the impossibility of quantitative comparison of the entity's parameters due to the various dimensions of the estimates, resulting in significant complications.

Therefore, to assess the performance, managers of domestic enterprises continue to apply the financial and economic analysis. In particular, this method is used in the research of Ukrainian scholars on the basis of a coefficient approach.

In Ukraine, the legislative approach to assessing the company's performance is reduced to an in-depth analysis of the financial and economic status of the "Methodology for in-depth analysis of the financial and economic situation of enterprises and organizations" [12].

It involves an analysis of the financial condition, production and economic activity of the enterprise, the results of which conclude whether it is expedient or impracticable to enter the company into the Register of insolvent enterprises and organizations, i.e., its efficiency or inefficiency.

It involves an analysis of the financial condition and production and economic activity of the enterprise, the results of which conclude whether it is expedient or impracticable to enter the company into the Register of insolvent enterprises and organizations, i.e., its efficiency or inefficiency.

However, domestic scientists offer other approaches meeting better the requirements of the market system of management [8], [21].

Widespread in Ukrainian practice are the methods of complex or multidimensional comparative assessment of the efficiency of the enterprise, targeted in two directions: the development of a single generalization indicator, which involves significant sides of economic activity, and the development of a computational algorithm, based on the system of indicators, which provide unambiguous assessment of the enterprise activity [14], [19].

Despite the availability of numerical methodological support and relatively little knowledge of the problem of the development of evaluation tools, the study showed no unified understanding of the procedure for assessing the performance of the activity.

Most of the existing techniques are limited to calculating a certain range of indicators and their aggregated levels, which varies greatly depending on the author's approach.

Some techniques are too general and do not take into account the specific features of enterprise development, others focus on the assessment of efficiency in specific areas only and are not aimed at forming a specific set of management measures based on the results of the study.

Among the issues that remain beyond the attention of scientists is the formation of a comprehensive vision of the assessment of retail business efficiency, taking into account the requirements of all stakeholders and industrial specifics.

At the heart of author's position is a modern vision of efficiency, which is based on such an approach to its achievement - the business entity has to manage the infrastructure of relations between the stakeholders, whose complexity and the strength of interconnections have to be determined by industry specifics.

And only in case of satisfaction of all stakeholders and their interests, the activity of the enterprise can be recognized effective.

Proceeding from the fact that the efficiency of the retail business is influenced by number of internal and external factors, the most relevant, promising and adequate to modern realities approach to its evaluation is the one based on the theory of stakeholders.

The composition of the parties involved in the retail business can vary significantly.

The most complete spectrum of participants was provided by the team of authors [13], who identified their enlarged groups: investors, clients, intermediaries, partnerships and alliances, suppliers, 
communities, hired workers, trade unions, influential groups, regulatory bodies and communities.

Among these groups, these authors examined in detail the impact of the most significant stakeholders - investors, clients and intermediaries, hired workers, suppliers, regulatory bodies and communities.

We emphasize that from the standpoint of the stakeholder approach the investor has a comprehensive character and can act simultaneously as: 1) a shareholder; 2) financial institution; or 3) another supplier of capital.

The shareholder as an investor acts as the owner of the company's capital and has the right to directly make managerial decisions regarding its current and future functioning.

The other two stakeholders, acting as an investor, do not participate in the management of the organization, usually limited to investing capital in the business structure, expecting from this operation a certain amount of profit only.

In order to form an adequate methodology for assessing the efficiency of retailers, we should distinguish the modern features of domestic retailers, detailed in previous studies [2].

Thus, the sector specifics of retail trade is connected, first of all, with its functional features and consists of: orientation to meet the needs of consumers in goods and services for end-use; the low capital intensity of the trade and production process due to the limited list of nomenclature positions of non-current assets, as well as their lower value in comparison with enterprises of other sectors of the economy; a significant rate of return on capital in comparison with low profitability and a short payback time of invested capital, which increases the attractiveness of retail; highly dynamic and agile trading activities, which promote rapid adaptation to changes in the consumer market and consumer demand; specific structure of capital; availability of a wide range of goods and services and a significant number of suppliers within one assortment group; prevalence in all regions of the country, etc.

Given the main provisions of the theory of stakeholders and the peculiarities of retail trade, the main stakeholders in the efficient operation of the retail business are directly the enterprise, the state, consumers, competitors, suppliers and financial institutions.

Thus, an effective methodology for assessing the performance efficiency should take into account the specifics of the activity of particular enterprise, its sector specificity, interests and requirements of a certain group of stakeholders.

\section{Methodology}

The Methodological basis of the research are general scientific and special methods of research are historical, monographic observation, formal-logical, analysis and synthesis, comparison and generalization, content analysis, interviewing, graphic, matrix, etc. [6], [10].

To obtain unambiguous results of the assessment of the efficiency of the retailers, an author's technique is based on the conceptual foundations of the theory of stakeholders and the main requirements of the resultant, target, resource and dynamic approaches to the assessment of efficiency has been developed.

Since efficiency acts as an estimation category and reflects the final qualitative result of human activity that occurs in the use of various resources, therefore, only one approach cannot be used during its evaluation, but it is necessary and appropriate to apply different approaches in a hierarchical sequence.

Thus, in order to assess the efficiency of the retail enterprise, it is proposed: firstly, to apply a target approach - mandatory achievement of a certain goal (retail company is effective only in case of achieving the goal of its activity); secondly, this goal should not be achieved in any way, but through the use of the minimum amount of resources and the cost of their involvement in order to achieve a definite result ("resource" and "productive" approaches), which will allow adapting to the existing economic situation in competitive environment in a best way due to the sustainability (dynamic approach).

In terms of the "target" approach, efficiency is considered as the degree of compliance of one or another phenomenon (actions) with the defined goals of the activity (functioning) of the socio-economic system (enterprise); as the performance of the enterprise in achieving the identified qualitative development goals in certain economic, sociopolitical, social and other conditions [2].

The necessity of applying this approach to the assessment is explained by the multiplicity of goals typical for retail business, which creates the basis for strategic decisions of economic entities, the implementation of which is ensured by tactical and operational measures that form the basis for control of the outcomes.

The level of achievement of objectives and completeness of the solution of the tasks is characterized by the success of the operation of the enterprise, thus reflecting its efficiency.

In accordance with the target approach, the "goal achievement" is chosen as the criterion of efficiency, which characterizes the degree of reach of certain goals of the retailer activity. 
The identification of the efficiency by this criterion is proposed to be carried out using the goal achievement factor (Rga) by the following formula:

$$
\mathrm{Rga}=\mathrm{acG} / \mathrm{plG}
$$

where acG - an actual goal; $\mathrm{plG}$ - a planned goal.

The application of the proposed factor provides for unambiguous identification of the activity as effective or ineffective. If $\mathrm{Rga} \geq 1$, that is, the actual goal is achieved $(\mathrm{Rga}=1)$ or some quantitative / qualitative parameters exceed the actual value (Rga $>$ $1)$, then the enterprise activity is effective.

Otherwise, it is ineffective.

According to the "productive" approach, efficiency is considered as performance, that is, the ratio of performance and resources spent to achieve these results.

This approach involves assessment of the efficiency as achieving a certain result from the implementation of a trading business, which may not necessarily be positive [4].

However, we stand for the point of view of authors [20], according to which "... the final results were not just the definition of the end of production, but the object of their real economic interests; definition and substantiation of goals and strategy of functioning on the basis of analysis of the peculiarities of their internal and external environment in the dynamic market economy have become top priority; the focus only on the rational use of resources has become insufficient".

Given this statement as a result from the standpoint of a productive approach, indicators with positive values are selected only (market volume, trading turnover, profit, etc.).

As a criterion for evaluating the efficiency within the framework of the effective approach, "performance" is chosen, which determines the degree of implementation of the planned results.

The identification of the efficiency by this criterion is proposed to be implemented using the performance factor (Rp) by the following formula:

$$
\mathrm{Rp}=\mathrm{acR} / \mathrm{plR},
$$

where acR - an actual result;

$\mathrm{plR}$ - a planned result.

The application of the proposed factor provides unambiguous identification of the retail business as effective or ineffective. If $\mathrm{pR} \geq 1$, that is, the planned results are achieved $(\mathrm{pR}=1)$ or some quantitative / qualitative parameters exceed the actual value $(\mathrm{pR}>$ $1)$, then the enterprise activity is effective.

Otherwise, it is ineffective.
The resource approach provides for a link between the resources of the company and its success in a competitive environment [1].

A resource approach to assessing the efficiency of a retail business is based on a comparison of the profit and consumption of a certain type of resource for its receipt [11]. This approach recognizes economic efficiency as obtaining a certain result per unit of resources used.

On the one hand, it is characterized by ease of use, since it does not require considerable time to find information about the meaning of the productive (trade turnover, profit) and estimated (diverse resources) enterprise performance indicator and the corresponding calculations; consequently, it is considered to be the most obvious and accurate.

The efficiency evaluation criterion within this approach is "resource cost", which characterizes the consumption of limited resources to achieve the determined indicators of the result.

The resource-cost ratio (Rrc) as an efficiency identifier based on this criterion is proposed to be determined as the ratio of the actual resource cost to the planned one (formulas 3-4):

$$
\mathrm{Rrc}=\mathrm{aRC} / \mathrm{plRC},
$$

where aRC - actual resource cost;

plRC - planned resource cost;

$$
\mathrm{RC}=\mathrm{R} / \mathrm{CR},
$$

where $\mathrm{RC}$ - resource cost;

$\mathrm{R}$ - performance result (for retailer - volume of product turnover, profit or other result);

CR - cost of a certain type of resources (labor, capital, etc.) to achieve the result (R).

The application of the proposed factor provides for unambiguous identification of the retail business as effective or ineffective. If $\operatorname{Rrc} \geq 1$, that is, the level of resource efficiency corresponds to the planned one $(\operatorname{Rrc}=1)$ or some quantitative / qualitative parameters exceed the actual value $(\operatorname{Rrc}>1)$, then the enterprise activity is effective. Otherwise, it is ineffective.

The dynamic approach is based on the consideration of time efficiency. In [16] highlights the static and dynamic efficiency of the organization.

This concept of static efficiency is consistent with what many call administrative economics. It is about the ability to adapt to the current economic situation and the to manage those units of a certain system that are not intended for further growth.

The dynamic efficiency shall mean any development tendency.

According to this approach, the assessment of the company's performance is carried out in dynamically different time intervals. 
The dynamics of the selected indicators, their comparison with similar data of other enterprises of the industry, which operate under the same conditions, indicates the efficiency or inefficiency of a separate retailer.

According to the dynamic approach, the retailer has to ensure efficiency over a period of time. The evaluation of the efficiency by this approach is proposed to be implemented using index dynamic indicators for all previous criteria (formulas 5-7):

1) goal achievement factor $(\operatorname{Id}(\mathrm{ga}))$

$$
\operatorname{Id}(\mathrm{ga})=\mathrm{Rga} 1 / \mathrm{Rga} 0
$$

where Rga1, Rga0 - factors of goal achievement in the reporting and baseline period, respectively;

2) performance factor $(\operatorname{Id}(p))$

$$
\operatorname{Id}(\mathrm{p})=\mathrm{Rp} 1 / \mathrm{Rp} 0
$$

where Rp1, Rp0 - factors of performance in the reporting and baseline period, respectively;

$3)$ resource cost factor $(\operatorname{Id}(\mathrm{rc}))$

$$
\operatorname{Id}(\mathrm{rc})=\operatorname{Rrc} 1 / \operatorname{Rrc} 0 \text {; }
$$

where Rrc1, Rrc0 - factors of resource cost in the reporting and baseline period, respectively.

The application of the index dynamic indicators provides for unambiguous identification of the retail business as effective or ineffective in a certain time period. If Id $\geq 1$, that is, the level of the reporting value of the factor corresponds to the base level ( $\mathrm{Id}=$ 1) or the reporting value exceeds the base one by some quantitative / qualitative parameters (Id > 1), then the retailer activity is effective over time.

Otherwise, it is ineffective over time. To facilitate identification of the retailer's efficiency an identification matrix has been developed (Table 1).

The proposed models for calculating performance indicators are general.

Table 1. Retailer's efficiency identification matrix. Source: Developed by the first author

\begin{tabular}{|c|c|c|}
\hline Criteria & Efficient & Inefficient \\
\hline \multirow{2}{*}{ Goal achievement } & $\begin{array}{c}\operatorname{Rga} \geq 1 \\
\operatorname{Id}(\mathrm{ga}) \geq 1\end{array}$ & $\begin{array}{c}\operatorname{Rga}<1 \\
\mathrm{Id}(\mathrm{ga})<1\end{array}$ \\
\hline \multirow{2}{*}{ Performance } & $\operatorname{Rp} \geq 1$ & $\operatorname{Rp}<1$ \\
& $\operatorname{Id}(\mathrm{p}) \geq 1$ & $\operatorname{Id}(\mathrm{p})<1$ \\
\hline \multirow{2}{*}{ Resource cost } & $\operatorname{Rrc} \geq 1$ & $\operatorname{Rrc}<1$ \\
& $\mathrm{Id}(\mathrm{rc}) \geq 1$ & $\operatorname{Id}(\mathrm{rc})<1$ \\
\hline
\end{tabular}

To formulate a methodology for assessing the efficiency of retail business based on the theory of stakeholders [7], [13], the relationship between the requirements and interests of identified stakeholders, the corresponding reciprocal actions of the retailer was identified, and the corresponding figures for the calculation models were specified (Table 2).

Table 2. Indicators of the efficiency of retailers by their main stakeholders Source: Developed by the first and second authors

\begin{tabular}{|c|l|l|}
\hline Stakeholder & \multicolumn{1}{|c|}{ Interests } & \multicolumn{1}{|c|}{ Indicators } \\
\hline Retailer & $\begin{array}{l}\text { Maximization of the market value of a business; optimal } \\
\text { income to risk ratio; cost optimization; rapid capital turnover; } \\
\text { improvement of efficiency, etc. }\end{array}$ & $\begin{array}{l}\text { The market value of the business; } \\
\text { financial performance; stock turnover }\end{array}$ \\
\hline State & $\begin{array}{l}\text { Economic growth and stable economic development; social } \\
\text { protection and employment of the population; innovative } \\
\text { development of the economy; formation of market } \\
\text { infrastructure; ecological safety }\end{array}$ & $\begin{array}{l}\text { Tax return; coefficient of employment } \\
\text { in trade; correlation of hired and } \\
\text { dismissed workers }\end{array}$ \\
\hline Consumers & $\begin{array}{l}\text { Product range variety; quality and safety of products, } \\
\text { accompanying services; satisfaction of changing } \\
\text { requirements }\end{array}$ & $\begin{array}{l}\text { Consumer satisfaction ratio; coefficient } \\
\text { of competitive advantage for the } \\
\text { product price; loyalty index }\end{array}$ \\
\hline Suppliers & $\begin{array}{l}\text { Fair competition } \\
\text { discipline; high responsibility for ensuring the established } \\
\text { conditions of the contract; gradual growth of sales volumes; } \\
\text { low risk of working with a buyer }\end{array}$ & $\begin{array}{l}\text { Market share in the competition group; } \\
\text { a variety of product range; product } \\
\text { turnover per 1 m2 of the trading area }\end{array}$ \\
\hline satisfaction
\end{tabular}

Given the above, the performance efficiency is proposed to be considered as the degree of achievement of goals, based on the optimal use of scarce resources for a specified period of time, subject to the specific requirements of the retailer's main stakeholders. 
The presentation of the developed methodology for assessing the retailer efficiency was carried out for the "Retail Enterprise" and "Consumers" stakeholders.

The interest of the enterprise itself in the development of its activities stems from the definition of entrepreneurship and its multidimensional nature and is associated with the direct receipt of profits, which serves as the main motive of economic activity and is a means for future development, effective use of available resources, optimization of costs, which finally promotes maximization of the market value of the enterprise.

The value of the "Consumers" in determining the ways to increase the efficiency of the retail business is due to the fact that the consumer forms the main parameters of efficiency - sales volumes, structure and variety of the product range, types and structure of services in the process of customer service, which ultimately make up a trade margin.

As specific indicators are to be used in the efficiency evaluation method from the standpoint of the retailer itself as a stakeholder, we propose in terms of the target approach to apply the indicator of the market value of the enterprise (NA), within the resource approach - turnover of inventories (IT), productive approach - financial performance of the enterprise (EBITDA).

The choice of these indicators is justified by the following logic.

The cost of an enterprise can be determined using the models of cost, income, and comparative approaches applied in valuation practice.

However, most of the valuation models cannot be used to assess the Ukrainian business due to the lack of a developed market and insufficient insider information about enterprises.

In some way, these shortcomings outline the valuation of the retail business by the net asset method, which was measured in the evaluation of the performance of the retailer.

The condition of ensuring a stable product range, uninterrupted sales of goods, which provides satisfaction of the demand of the population, improvement of the quality of service, increase in the competitiveness of the retailer is commodity stocks as one of the important resources of trading enterprises.

Therefore, the rate of turnover of commodity stocks, on the one hand, determines the security of commodity turnover of the retailer, and on the other characterizes the performance of their use.

Given that the interests and requirements of any commercial enterprise are aimed at obtaining a certain result, the best for its display is a measure of financial performance [3], which is the total earnings before interest, taxes, depreciation, and amortization of the enterprise.

When choosing indicators from the standpoint of consumers as a stakeholder within the framework of the targeted approach, it is expedient to focus on providing consumers with the conditions for the greatest satisfaction with the purchased product (accordingly, it is proposed to use the consumer satisfaction index (ICS)); within the resource approach, one needs to focus on the consumer's demand for saving time, money related to the search for and acquisition of a particular product (price competitiveness index); and within the productive approach - on ensuring the maximum value of trade services for the consumer (net promoter score NPS).

The selected indices are proposed to be analyzed solely from the standpoint of consumers as the determining factor in the existence of a retail company.

This stipulates the goal achievement of using such methods as questionnaires, scoring and rating, to determine these indicators.

At the same time, the price competitiveness index is proposed to be determined by comparing with the maximum number of competitive advantages in the competitive group of retailers that meet consumer demands regarding the price of goods.

The consumer satisfaction ratio is proposed to be determined as the ratio of changes in positive and negative feedback over a defined time period.

The net promoter score reflects the willingness of buyers to continue buying products from a trading company.

The retailer efficiency evaluation method with regarding to the interests of the "Retailer" and "Consumers" is to ensure the consistent implementation of the three stages (Figure 1).

The first stage involves the formation of a database in the form of the required amount of internal and external data on the object of evaluation, which completeness and validity determines the objectivity of the results obtained and the recommendations provided.

The database is formed in accordance with the requirements of a separate stakeholder in accordance with the selected indicators.

The main sources of information for assessing the efficiency of the retailer can be divided into internal (financial statements of the entity, data of accounting, operational and technical and managerial reporting, etc.) and external (statistical, regulatory and reference and market information).

At the second stage, calculations are carried out according to the proposed evaluation system.

The developed system for assessing the retailer efficiency is based on the basic principles of target, 
productive, resource and dynamic approaches and represents a set of subsystems of the determined industry indicators of efficiency according to the chosen criteria.

Criteria for assessing efficiency meet the approaches to evaluation and may vary depending on subject of its conduct.

Criteria are quantitatively implemented in specific indicators, which provide an objective assessment of economic activity and its efficiency.
During the third stage, based on the results of the evaluation of the developed system of criteria and indicators, specific conclusions are drawn about the state of the efficiency of the retailer, the factors of influence are determined and the directions of management actions are substantiated, which will provide positive changes and promote the development of the retailer taking into account the defined strategy in the context of formation of its competitive advantages.

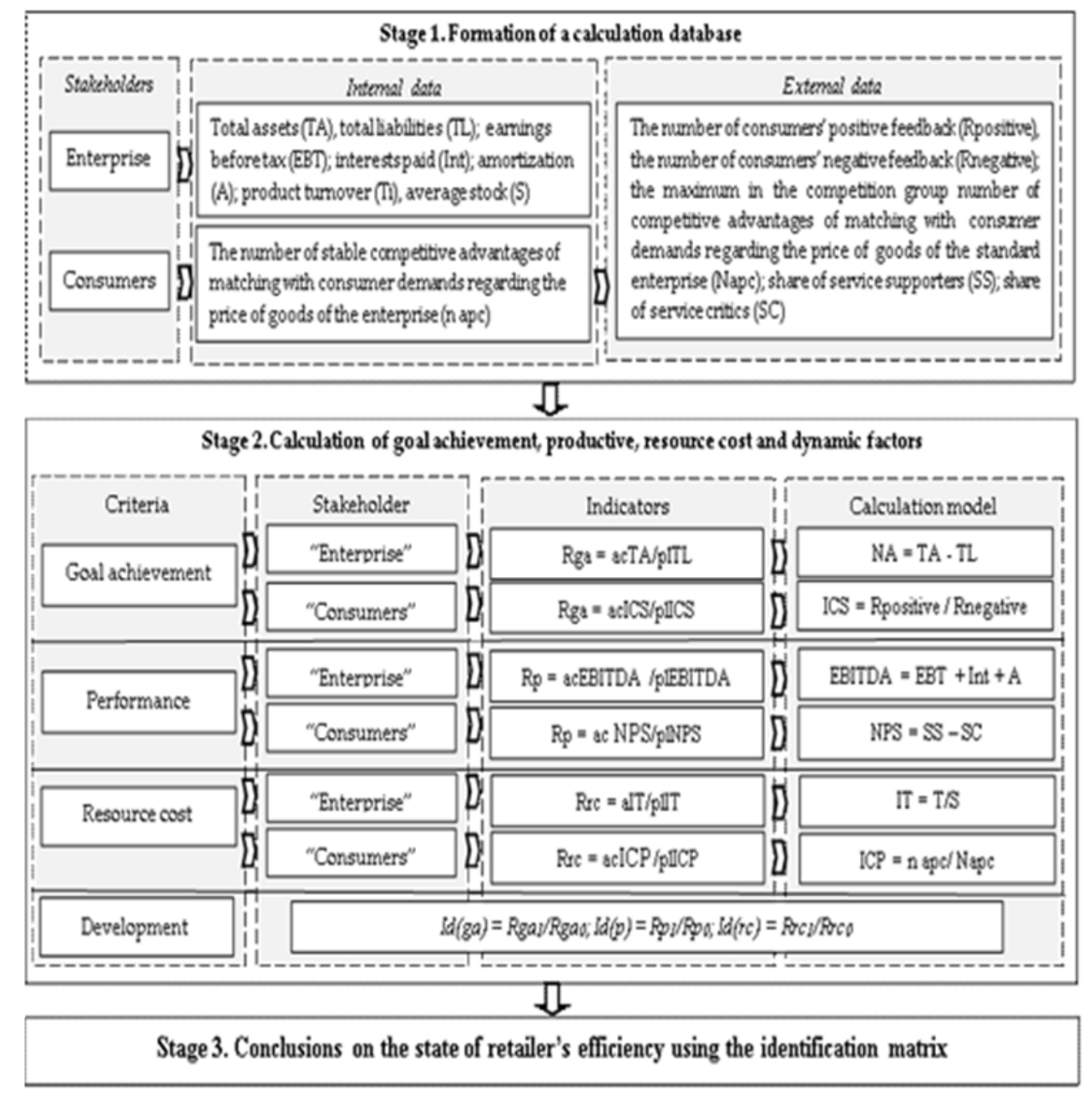

Figure 1. The stages of the retailer's efficiency evaluation for "Retailer" and "Consumers" Source: Developed by the authors

The result of the proposed methodology is the evaluation of the efficiency based on the identification matrix, which ensures a clear and unambiguous interpretation of the findings and can be used by different stakeholders.

\section{Results and Discussion}

The implementation of the developed methodology for evaluating the retailer efficiency was carried out using the local trading chain, "Rost", LLC "Modern" (Kharkiv, Ukraine) as an example, according to the information service smida.gov.ua and the survey results for the "Consumers" stakeholder.
The results of calculating the efficiency indicators for the defined assessment approaches in 2018-2019 years are shown in Table 3 and entered in the identification matrix in Tables 4 and 5.

Table 3. Calculation results of the ratios of goal achievement, performance, resource cost for assessing the efficiency of the trading chain "Rost", LLC "Modern".

Source: Developed by the authors

\begin{tabular}{|l|c|c|}
\hline \multicolumn{1}{|c|}{ Indicators } & $\mathbf{2 0 1 8}$ & $\mathbf{2 0 1 9}$ \\
\hline $\begin{array}{l}\text { Goal achievement ratio } \\
\text { (by net asset value) }\end{array}$ & 1.218 & 1.154 \\
\hline $\begin{array}{l}\text { Performance ratio } \\
\text { (financial performance) }\end{array}$ & 0.681 & 0.931 \\
\hline $\begin{array}{l}\text { Resource cost ratio } \\
\text { (product turnover) }\end{array}$ & 0.691 & 0.661 \\
\hline
\end{tabular}




\begin{tabular}{|l|c|c|}
\hline & "Consumers" & \\
\hline $\begin{array}{l}\text { Goal achievement ratio } \\
\text { (consumers' satisfaction) }\end{array}$ & 1.113 & 0.938 \\
\hline $\begin{array}{l}\text { Performance ratio } \\
\text { (net promoter score) }\end{array}$ & 1.046 & 1.045 \\
\hline $\begin{array}{l}\text { Resource cost ratio } \\
\text { (advantages of price } \\
\text { competitiveness) }\end{array}$ & 1.035 & 1.136 \\
\hline
\end{tabular}

Table 4. Efficiency identification matrix of "Modern" from standpoint of "Retailer".

Source: Developed by the authors

\begin{tabular}{|c|c|c|}
\hline Criteria & Efficient & Inefficient \\
\hline $\begin{array}{l}\text { Goal } \\
\text { achievement }\end{array}$ & $\begin{array}{l}R g a_{2016}=1.218 \\
R g a_{2017}=1.154\end{array}$ & $\operatorname{Id}(g$ \\
\hline Performance & 1.367 & $\begin{array}{l}R p_{2016}=0.681 \\
R p_{2017}=0.931\end{array}$ \\
\hline Resource cost & & $\begin{aligned} R r c_{2016} & =0.691 \\
R r c_{2017} & =0.661 \\
I d(r c) & =0.957\end{aligned}$ \\
\hline
\end{tabular}

Table 5. Efficiency identification matrix of "Modern" from "Consumers" standpoint.

Source: Developed by the authors

\begin{tabular}{|l|c|c|}
\hline \multicolumn{1}{|c|}{ Criteria } & Efficient & Inefficient \\
\hline $\begin{array}{l}\text { Goal } \\
\text { achievement }\end{array}$ & $R g a_{2016}=1.113$ & $\begin{array}{c}\operatorname{Rg} a_{2017}=0.938 \\
I d(g a)=0.843\end{array}$ \\
\hline Performance & $R p_{2016}=1.046$ & $I d(p)=0.999$ \\
& $R p_{2017}=1.045$ & \\
\hline \multirow{3}{*}{ Resource cost } & $\begin{array}{l}R r c_{2016}=1.035 \\
\end{array}$ & $R r c_{2017}=1.136$ \\
& $I d(r c)=1.098$ & \\
\hline
\end{tabular}

The business activity of "Suchasnyi modern" from the standpoint of "Retailer" (Figure 3) was efficient by goal achievement ratio in 2018-2019 (the planned net asset value was achieved), however, over time, its efficiency decreases (the reported value is lower than the base $(\mathrm{Id}<1)$.

The business activity is ineffective in terms of the performance criterion throughout the study period (the planned value of financial performance was not achieved), but over time the reporting value $\mathrm{Rp}$ is higher than the base $(\operatorname{Id}(\mathrm{p})>1)$.

By the criterion of resource cost, the retail business activity was ineffective both in statics and over time.

From the standpoint of "Consumers", the activity in 2018 is interpreted as effective in all three criteria, as evidenced by the value of the respective ratios.

In 2019, the company failed to achieve the planned target value of consumer satisfaction both in statics and over time. From the standpoint of net promoter score, there is a decrease in the efficiency of the enterprise over time.

At the same time, according to the competitive advantages that correspond to consumer demands regarding the price of goods, the activity of the investigated trading chain is efficient throughout the study period (as evidenced by the value of the resource cost ratio and index).
Based on the results of the conducted efficiency assessment by the proposed method, the retailer can uniquely identify the most important factors of influence and substantiate the directions of management actions, which will provide positive changes and promote the development of the retailer taking into account the defined strategy in the context of formation of its competitive advantages.

\section{Conclusions}

This paper analyzes the existing methods of evaluating the efficiency of enterprises and identifies their following disadvantages: 1) complicated calculation procedure that makes them difficult to use by small and medium-sizes enterprises; 2) often provide for the calculation of multi-direction indicators of evaluation, which does not ensure unambiguous conclusions; 3) neglect the sector specifics of Ukrainian retail activity, the requirements and needs of the main stakeholders to the assessment of efficiency, etc.

The advantages of the proposed author's technique for assessing retailer efficiency are:

- considers the specifics of retail activities and the Ukrainian business realities;

- allows determining the state of efficiency of retail business by three components (goal achievement, performance, and resource cost) in static and over time;

- -the choice of specific indicators for the evaluation of efficiency depends on the stakeholder, which involves the variation of evaluation indicators within one criterion;

- meets the criteria of sufficiency and simplicity.

The author's retailer efficiency assessment technique outlines the main principles and directions of evaluation, specifies the algorithm for calculating the indicators in accordance with the selected approaches to the evaluation, and provides the specific stakeholder with flexibility and considerable autonomy in choosing the goals, results, resources for their implementation both in statics and over time.

This technique took into account the interests of all identified stakeholders in assessing the efficiency of the enterprise in the context of achieving competitive advantages in retail trade.

Further research in this direction is aimed at the implementation of the developed technique in the business activities of retailers different in size, specialization, format, location, and etc.

Theoretical relevance is the next. The conceptual foundations of the evaluation of the efficiency of retailers have been developed, presented as a single set of the determined elements of evaluation (subject, object, approaches, criteria, indicators, information provision), took into account the sector specifics of 
retail trade and the requirements of the main stakeholders, which ensures high adequacy of the results of evaluation for all directions and components.

Practical relevance is the next. The retailer efficiency assessment technique has been developed, based on the principles of the theory of stakeholders, which considers the specifics of retail trade and provides the consistent implementation of three stages: the formation of a calculation database; calculation of ratios of goal achievement, performance, resource cost and dynamics; conclusions about the state of the activity of the retailer with the help of the identification matrix.

The system of indicators of economic efficiency of retailers has been proposed, which characterizes the relationship between the company and the main stakeholders and ensures evaluation in terms of goal achievement, performance, resource cost, and development.

The effectiveness of this technique in the chain of supermarkets "Rost", LLC "Modern" (Kharkiv, Ukraine) has been experimentally proved.

The results of the study can be used in the evaluation practice of retailers to form effective management decisions in developing strategies and action plans subject to the requirements of stakeholders.

\section{References}

[1]. Barney, J. (1991). Firm resources and sustained competitive advantage. Journal management, 17(1), 99-120.

[2]. Chorna, M. V. (2010). Upravlinnia konkurentospromozhnistiu pidpryiemstv rozdribnoi torhivli: teoretyko-metodolohichni zasady ta praktychnyj instrumentarij [Management of competitiveness enterprises of retail trade: theoretical and methodological bases and practical tools]. KhDUKhT, Kharkiv, Ukraine.

[3]. Koller, T., Goedhart, M., \& Wessels, D. (2010). Valuation: Measuring and Managing the Value of Companies (Vol. 499). John Wiley \& Sons.

[4]. Dolan, E., Lindsey, D. (1991). Economics. Chicago: The Dryden Press.

[5]. Drucker, P. F. (1991). The New Productivity Challenge. Harvard business review, 69(6), 69.

[6]. Dul, J., Hak, T. (2008). Case Study Methodology in Business Research. Amsterdam: ButterworthHeinemann.

[7]. Parmar, B. L., Freeman, R. E., Harrison, J. S., Wicks, A. C., Purnell, L., \& De Colle, S. (2010). Stakeholder theory: The state of the art. Academy of Management Annals, 4(1), 403-445.
[8]. Iljash, O., Ghetjmansjkyj, V. (2014). Teoretykometodychni zasady ta prykladni rekomendaciji ocinjuvannja efektyvnosti funkcionuvannja torghoveljnykh pidpryjemstv $\mathrm{v}$ umovakh ekonomichnogho rozvytku [Theoretical and methodological foundations and applied recommendations for evaluating the performance of trading enterprises in the context of economic development]. Problems of the economy. 3, 220-226. (In Ukrainian).

[9]. Kaplan, R. S., \& Norton, D. P. (1996). Using the balanced scorecard as a strategic management system. Harvard Business Review, 74(1), 75-85.

[10]. Kothary, C. (2014). Research Methodology: Methods and Techniques. New Delhi: New Age International Publishers.

[11]. Mescon, M. H., Albert, M., \& Khedouri, F. (1988). Management. Tierd edition.

[12]. Metodyka provedennja poghlyblenogho analizu finansovo-ghospodarsjkogho stanu pidpryjemstv ta orghanizacij [Methodology for in-depth analysis of the financial and economic situation of enterprises and organizations]. Retrieved from: http://zakon2.rada.gov.ua/laws/show/z0288-97 [accessed: 30 January 2021]. (In Ukrainian)

[13]. Adams, C., Neely, A., \& Kennerley, M. (2002). Performance prism: the scorecard for measuring and managing stakeholder relationships. Financial Times/Prentice Hall, London.

[14]. Novakivsjkyj, I. (2017). Systema upravlinnja pidpryjemstva $\mathrm{v}$ informacijnomu suspiljstvi [Enterprise management system in the information society]. Ljviv: Nacionaljnyj universytet «Ljvivsjka politekhnika». (In Ukrainian)

[15]. Pezet, A. (2009). The history of the french tableau de bord (1885-1975): evidence from the archives. Accounting, Business \& Financial History, 19(2), 103-125.

[16]. Schumpeter, J. A. (2003). Capitalism, Socialism y Democracy. London and New York: Taylor \& Francis e-Library.

[17]. Stewart, B. (1999). The Quest for Value. The EVA management quide. New York: Harper Business.

[18]. Tobin, J. (1965). Money and Economic Growth. Econometrica, 33(4), 671-684.

[19]. Troyanova, E. N. (2015). Metodika otsenki effektivnosti deyatel'nosti predpriyatiya $\mathrm{s}$ uchetom rynochnoy situatsii. Biznes. Obrazovanie. Pravo. Vestnik Volgogradskogo instituta biznesa, (2), 31.

[20]. Tishchenko, A. N., Kizim, N. A., \& Dogadaylo, Y. V. (2005). Ekonomicheskaya rezul'tativnost'deyatel'nosti predpriyatiy [Economic performance of enterprises]. Kharkiv: INZhEK. [in Russian].

[21]. Vlasova, N., Pichughina, T., Krughlova, O., Ghajdar, N. (2012). Ocinka efektyvnosti ghospodarsjkoji dijaljnosti pidpryjemstv rozdribnoji torghivli [Evaluation of the economic performance of retail enterprises]. Kharkiv: Vyd-vo Ivanchenka (In Ukrainian). 